\title{
Outcome of criminal investigation into allegations of sexual abuse
}

\author{
Camille San Lazaro, Alison M Steele, Liam J Donaldson
}

\begin{abstract}
The aim was to study the outcome of criminal investigation into allegations of sexual abuse made by 160 children assessed over a two year period in a specialist paediatric unit in the North of England. In all, 141 of the 160 children $(88 \%)$ were female, and 99 (62\%) were aged under 12 years. There were 145 males and nine females named by children in allegations of sexual abuse. Fathers formed the largest single group of alleged male perpetrators (56/176). None of the nine alleged female abusers was prosecuted. Of the 145 males, 57 reached trial; 49 were convicted, an $86 \%$ conviction rate of those sent to trial and a rate of proven sexual offence (including cautions) of $44 \%$ (54/124) among men originally interviewed by the police. Twenty five per cent of children (17/68) who could have testified did so, most giving evidence against someone who was known to them. Pragmatic selection of cases for prosecution resulted in an outcome highly vindicating of the decision to prosecute. The possible effects of this process are discussed.

(Arch Dis Child 1996;75:149-152)
\end{abstract}

Keywords: sexual abuse, prosecution, conviction rate, criminal justice system.

The process of dealing with allegations of child sexual abuse was widely debated following criticism of child protection services in Cleveland, England, in the mid-1980s. ${ }^{12}$ Since then, there have been other occasions when the response of services to the problem of sexual abuse in children has resulted in widespread public concern. ${ }^{3}$

Less attention has been given to the role

University of

Newcastle upon Tyne,

Department of Child

Health

C San Lazaro

A $M$ Steele

Department of Epidemiology and Public Health

L J Donaldson

Correspondence to: Dr C San Lazaro, Department of Child Health, The Lindisfarne Centre, Royal Victoria Infirmary, Newcastle upon Tyne NE1 4LP.

Accepted 24 April 1996 sense that there has been societal acknowledgement of grievance. If there is proper preparation, and the resolution is speedy, testifying in court may be beneficial for children. Moreover, there is a public interest in ensuring the protection of communities against offenders.

Among professionals, there seems to be a perception that the prosecution process has a poor outcome and so its credibility has been reduced as an inherent part of the professional approach to child abuse intervention. However, relatively little has been reported about the outcome of criminal investigation following allegations of sexual abuse.

In this paper we describe a study of those cases of alleged sexual abuse referred to a specialist paediatric service which became the subject of referrals to the police.

\section{Methods}

The study population was those people living in the area of the former Northern Regional Health Authority encompassing the counties of Tyne and Wear, Durham, Northumberland, Cleveland, and Cumbria. The region was one of the 14 regions into which at the time the National Health Service in England was divided geographically and administratively. The population of the region was approximately three million.

The clinical department in which cases in the study were assessed is a specialist paediatric unit (the Lindisfarne Centre) located in one of the major hospitals in Newcastle upon Tyne. It is the only such unit in the Northern Region. While cases may be referred to the unit from anywhere in the region, in practice they usually come from the Tyneside and Wearside conurbation and therefore include most of Newcastle upon Tyne cases, some from Sunderland and other urban conurbations (such as Gateshead), as well as some from rural communities. The centre has integral facilities for video interviewing of children and during the study period pilot use of the facilities was undertaken by police child protection and social workers.

Cases considered for inclusion in the study were all referrals of children and young people aged under 16 years made to the Lindisfarne Centre during the two year period 1 July 1989 to 30 June 1991 (inclusive) in whom there was a concern about possible sexual abuse. Only children who had made a clear statement describing sexual assault either before or during paediatric assessment were included in the study. All the children in the study were assessed by one of us (CSL). validation and self assertion. ${ }^{78}$ It may serve as a psychological sealant to trauma as a final watershed event where public airing provides a 
Table 1 Age and sex in the study population

\begin{tabular}{lccc}
\hline Age group (years) & Male & Female & Both sexes \\
\hline Under 4 & 2 & 14 & 16 \\
$4-7$ & 9 & 35 & 44 \\
$8-11$ & 4 & 35 & 39 \\
$12-15$ & 4 & 57 & 61 \\
All ages & 19 & 141 & 160 \\
\hline
\end{tabular}

All children and young people seen in the Lindisfarne Centre had a detailed paediatric assessment carried out. The results were recorded in a structured proforma which gathered information on family circumstances, details of the suspected abuse, developmental and medical history, the nature of the allegation, and the physical and forensic examination.

Data concerning alleged perpetrators were extracted from the proforma and included data relating to their age, sex, and their relationship to the child. The police provided any missing information on the outcome of investigation and details of charges and trial outcome.

All data concerning individuals were an integral part of the case records and no additional information was sought directly from them. All data were extracted in anonymous form and aggregated so that at no time could any individual be identified through the analyses.

\section{Results}

During the study period 160 children were seen who had made what was deemed to be an unequivocal allegation of sexual abuse mandating police investigation. The children were referred by police alone (18\%), social workers alone $(4 \%)$, joint police/social work referrals $(62 \%)$, health referrals $(16 \%)$, and others $(1 \%)$.

The great majority, $88 \%$ (141/160), were girls and $62 \%(99 / 160)$ of all children were aged under 12 years (table 1 ). The median age of the boys was 7.7 years (range 3.5 to 14.5 years), and of the girls, 10.3 years (range 2.2 to 15.9 years).

Table 2 shows the nature of abuse alleged before or at paediatric assessment. There were 151 allegations of penetrative acts, of which 110 involved vaginal penetration and 41 anal penetration. Most children made allegations of more than one type of sexual contact.

There were 145 males whom children named in allegations of abuse. There was a complex relationship between alleged male perpetrators and the children; some children named more than one perpetrator (up to a

Table 2 Nature of sexual abuse alleged

\begin{tabular}{lll}
\hline Nature of abuse & No of children & Percentage of children \\
\hline Fondling of genitalia and/or breasts & 105 & 66 \\
Penile penetration of vagina & 52 & 33 \\
Digital penetration of vagina & 54 & 34 \\
Instrumentation of vagina & 4 & 3 \\
Penile penetration of anus & 28 & 18 \\
Digital penetration of anus & 10 & 6 \\
Instrumentation of anus & 3 & 2 \\
Adult mouth to genitalia & 25 & 16 \\
Child mouth to genitalia & 26 & 16 \\
Simulated sexual intercourse & 23 & 14 \\
\hline
\end{tabular}

Table 3 Relationship to the alleged male perpetrator

\begin{tabular}{lccc}
\hline Relationship to child & Boys & Girls & Both sexes \\
\hline Natural father & 2 & 30 & 32 \\
Stepfather & 6 & 18 & 24 \\
Grandfather & 0 & 5 & 5 \\
Brother & 1 & 9 & 10 \\
Other relative & 1 & 18 & 19 \\
Person in trust & 7 & 37 & 44 \\
Stranger & 5 & 37 & 42 \\
Total & 22 & 154 & 176
\end{tabular}

Note: some children made allegations about more than one person.

Table 4 Outcome in male suspects

\begin{tabular}{lc}
\hline Outcome & No of male suspects \\
\hline Not interviewed & 19 \\
No record of whether interviewed & 2 \\
Interviewed but not charged & 57 \\
Cautioned & 6 \\
Found guilty on any charge & 49 \\
Found not guilty on any charge & 8 \\
'Lost' & 5 \\
Total & 146 \\
\hline
\end{tabular}

maximum of five), and some perpetrators were named by more than one child. This resulted in 176 alleged abusive associations between children and male perpetrators. The nine females who were named by children were involved in 12 alleged abusive associations, with one male and 11 female children. Three were not interviewed, either because of their age or the quality of the statement given by the child. None was prosecuted. This group included four mothers all named as co-abusers with an adult male partner. Twenty three of all the people accused of perpetrating abuse were aged under 16 years at the time (18 boys and five girls).

Table 3 shows the relationship between the alleged male perpetrators and the child. Natural fathers and established non-biological male parents (stepfathers) together formed the largest group-56 out of 176 associations (32\%). The second largest group consisted of people into whose care the child was entrusted. These included mothers' boyfriends, baby sitters, teachers, and others known to and trusted by parent or child. Stranger abuse occurred in 42 out of 176 associations (24\%). 'Strangers' included people who were casual acquaintances of the family with no special role in the child's life and also absolute strangers.

Table 4 shows the outcome with male suspects after police involvement. Of the 145 males, 19 were never interviewed. Reasons included retractions, inadequate or confused statement, perpetrators not found, and child or parent not wishing to proceed (against other children). There was no record of an interview in two cases. Of 124 definitely interviewed, five were cautioned having admitted an offence and 62 were charged with intent to prosecute (one of whom was also cautioned). Of those charged, two absconded and were never found, while in two further cases, the charges were dropped because the child was deemed unable to testify. Court data were unavailable in one other case. Fifty seven males were brought to trial as a result of allegations involving 68 
Table 5 Nature of 102 original charges preferred

\begin{tabular}{lllllll}
\hline Rape & Attempted rape & USI & Buggery & Indecent assault & Gross indecency & Other \\
\hline 11 & 7 & 9 & 13 & 53 & 7 & 2 \\
\hline
\end{tabular}

USI = unlawful sexual intercourse.

children within 72 abusive associations. Of these, $49(86 \%)$ were convicted of sexual assault, eight were acquitted of any offence (although one of those acquitted in our series was convicted in the same trial of five other sexual offences, against other children).

Table 5 shows the nature of the 102 charges originally brought against the 57 male alleged perpetrators of abuse, while table 6 shows the pattern of convictions actually obtained at the trial of each person. In all, 49 of those men convicted were convicted on 75 charges. Thus, given that 124 males were originally interviewed by police, the 49 convicted at trial together with the five only cautioned represent a rate of proven sexual offence of $44 \%$ (54/124) of investigated child sexual abuse allegations against male suspects.

Physical signs were noted in 110 of the 160 children (69\%) and in 52 of the 68 children involved in trials (76\%). The unusually high rate of findings in this group is being studied, along with the findings in all children referred for suspicion of sexual abuse in the study period. Four children in whom there was no physical evidence were linked to other children in whom evidence was present. In all $25 \%$ of children testified at trials $(17 / 68)$. Of the 17 testifying, two did so against strangers, while the majority were giving evidence against someone who was known to them: fathers (six), stepfathers (four), brothers (one), or other trusted person (four). Information was available regarding court dates in the cases of 59 of the children and, based on these cases, the time from initial assessment to trial was a median of 260 days (14-552 days).

\section{Discussion}

Children presenting to a specialist paediatric centre are not representative of the spectrum of sexually abused children in the population. However, we believe that the nature of abuse reported may not be greatly different to that presenting to the paediatric services in any large urban area in the UK. Comparison with previous studies is in any case made difficult by definitional and methodological variation, a subject which has recently been reviewed. ${ }^{9}$

In discussions about the goals and orientation of the child protection service, relatively little attention has been given to establishing what the value of the criminal justice system is within the overall process. The Offences Against the Person Act 1861, Section 1 of the Children and Young Persons Act 1933, and the Sexual Offences Act 1956 state that assault, ill treatment, or neglect of children are crimes. However, the detection and treatment of child abuse crosses professional boundaries.

One role of the criminal justice system is to encourage offenders to accept responsibility for behaviour and enter treatment. ${ }^{10}$ However, there are other purposes. Firstly, the criminal justice process must reinforce the values of the community and give appropriate messages to offenders about the unacceptable deviancy of their behaviour. Secondly, there is a role in the protection of children: a custodial sentence results in the physical withdrawal of the offender from the community. Any conviction results in the listing of the offender under Schedule 1 of the Children and Young Persons Act 1933. This creates a mandate for early monitoring of children at risk. Thirdly, there are the possible beneficial effects on the child. Children may feel encouraged by their participation in the process and from learning that social institutions take them seriously. ${ }^{7}$

Against all these considerations must be balanced the possible adverse effects upon some children's welfare through involvement in the process. The stress of long delays, having to testify, and the effect of an acquittal are of most concern.

The outcome for prosecution is thought to be poor in child sexual abuse cases. In our series, however, the judicious selection of cases and careful modification of charges appears to have resulted in the sparing of many children from testimony. Moreover, convictions were achieved in up to $86 \%$ of cases tried. Serious contact abuse was usually described in the allegations and this provided an established mandate for police intervention. However, we also found that criminal convictions from guilty pleas tended to be achieved from charges implying less serious abuse than alleged. In contrast, a paper by De Jong and Rose from Philadelphia ${ }^{11}$ suggested that their group of perpetrators was more likely to be charged with the more serious offences and less likely to plead guilty. Despite this, their conviction rate was $76 \%$, and $77 \%$ of their convictions appeared to depend on the quality of verbal evidence and the effectiveness of child testimony, without physical evidence of sexual assault.

A recent review of prosecution in child abuse in the $\mathrm{UK}^{12}$ shows that despite wide acknowledgement that delays are detrimental to

Table 6 Outcome of trials of alleged male perpetrators of sexual abuse

\begin{tabular}{llllllll}
\hline & \multicolumn{2}{l}{ Charge } & & & & \\
\cline { 2 - 8 } Outcome of trial & Rape & $\begin{array}{l}\text { Attempted } \\
\text { rape }\end{array}$ & USI & Buggery & $\begin{array}{l}\text { Indecent } \\
\text { assault }\end{array}$ & $\begin{array}{l}\text { Gross } \\
\text { indecency }\end{array}$ & Other \\
\hline Convicted on original charge & 4 & 1 & 7 & 6 & 38 & 6 & 1 \\
Convicted on altered charge & 5 & 4 & 0 & 4 & 1 & 1 & 0 \\
Aquitted of all charges & 1 & 0 & 1 & 1 & 5 & 0 & 1 \\
Total initially charged with this offence & 10 & 5 & 8 & 11 & 44 & 7 & 2 \\
\hline
\end{tabular}

USI = unlawful sexual intercourse. 
children's welfare, such delay remains common. This was so in our series, where the median time from assessment to court was 260 days. Court delays are highly disruptive to children and families, victims may be pressurised into retraction, support systems may not survive, and the child tends to be preoccupied with the abuse and be unable to engage in therapy. ${ }^{13}$

In our series, like others, ${ }^{14-16}$ most of the alleged perpetrators were adult males: biological and non-biological male parents together formed the largest group named as perpetrators. There is a commonly held belief that those closest to the child would be less willing for the child to go through the ordeal of a court case. This was not so in our series. Seventeen children in our study actually testified in court proceedings, $88 \%$ of these children testifying against defendants who were close to them and who had a significant role in their lives.

To our knowledge, no study has been conducted to examine the outcome for mental health in this group compared to children who testify against defendants who are not so related to their lives. Our clinical experience is that children report prolonged fear about the power and capacity for vengeance of perpetrators whom they do not know and of whose whereabouts they are uncertain. However, the loss of a parent, the break up of family and the sense of guilt or betrayal is also likely to contribute major psychological stress in those victims who testify against a family member, especially a parent.

None of the female alleged perpetrators in our study was cautioned or charged. Deep rooted cultural and ideological belief systems within a variety of political groups have in recent times generated a lobby for the highlighting of women-as-victim status. Although there has been an ethos of denial that females abuse, there is now increasing awareness about female abusers. Rowan et $a l^{17}$ suggested that women are usually co-abusers with a dominant male partner, as well as often being of limited intelligence or mentally ill. However, Matthews ${ }^{18}$ in her work with female abusers has found considerable diversity and complexity in this group. It is clear that many women act alone and initiate abuse. Our more recent experience of women abusers accords with her findings.

A historical problem of long delays and the acknowledged antitherapeutic potential of structures designed for adult witnesses has sadly resulted in a degree of pragmatism in electing to prosecute. We believe that pretrial preparation of children should focus on realistic expectations of the process. We also hope that fast tracking of cases, increasing skills in video evidence, and sensitivity to the needs of the child in court will all result in younger children being able to avail themselves of the process.

In this series, cautious selection of cases and charges for prosecution has resulted in a high conviction rate. This approach has meant that many children have been spared the court experience. However, we are aware that many children and families also feel deeply disappointed by decisions not to prosecute. Even in those cases prosecuted, our clinical experience of debriefing of children and families would suggest that the reduction of severity of charges and the variability of sentencing does result in feelings of disappointment, anger, and a sense of anticlimax. However, with appropriate preparation, and post-trial counselling, some adverse effects could be minimised and the trial-whatever its outcome-perceived as a closure event. Since the study period, modifications to the system have been both implemented $^{19}$ and studied. ${ }^{20}$ Most practitioners would agree that these changes have brought new problems and have not effectively resolved the old.

There remains wide professional concern about the antitherapeutic nature of the whole criminal justice process, particularly the trauma of cross examination in trials.

We thank Detective Chief Inspector Blue and the staff of the Northumbria Police Child Protection Units for their support and assistance.

1 Department of Health and Social Security. Report of the enquiry into child abuse in Cleveland. $\mathrm{Cm}$ 413. London: HMSO, 1988.

2 Donaldson LJ, O'Brien S. Press coverage of the Cleveland child sexual abuse enquiry: a source of public enlightenment? ₹ Public Health Med 1995;17:70-6.

3 Clyde JJ. The report of the inquiry into the removal of children from Orkney in February 1991. HC 185. London: HMSO, from Or.

4 Newberger EH. Prosecution: a problematic approach to child abuse. F Interpersonal Violence 1987; March:112-7.

5 Landwirth J. Children as witnesses in child sexual abuse trials. Pediatrics 1987;80:585-9.

6 Runyan DK, Everson MD, Edelsohn GA, Hunter WM, Coulter ML. Impact of legal intervention on sexually abused children. $₹$ Pediatr 1988;113:647-53.

7 Berliner L, Barbieri MK. The testimony of the child victim of sexual assault. $\mathcal{F}$ Soc Issues 1984;40:125-37.

8 Eth S. The child victim as a witness in sexual abuse proceedings. Psychiatry 1988;51:221-32.

9 Pilkington B, Kremer J. A review of the epidemiological research on child sexual abuse: clinical samples. Child Abuse Rev 1995;4:191-205.

10 Graves PA, Sgroi SM. Law enforcement and child sexual abuse. In: Sgroi SM, ed. Handbook of clinical intervention in child sexual abuse. Mass: Lexington Books, 1982:309-33.

11 De Jong AR, Rose M. Legal proof of child sexual abuse in the absence of physical evidence. Pediatrics 1991;88:50611 .

12 Plotnikoff J, Woolfson R. Prosecuting child abuse: an evaluation of the Government's speedy progress policy. London: Blackstone Press, 1995.

13 Schetky DH, Benedek EP. The sexual abuse victim in the courts. Psychiatr Clin North Am 1989;12:471-81.

14 Baker AW, Duncan SP. Child sexual abuse: a study of the prevalence in Great Britain. Child Abuse Negl 1985;9:45767.

15 Finkelhor D, Lewis IA, Hotaling G, Smith C. Sexual abuse in a national survey of adult men and women: prevalence, characteristics, and risk factors. Child Abuse Negl 1990; 14:19-28.

16 Hobbs CJ, Hanks HGI, Wynne JM. Sexual abuse-the scope of the problem. Child abuse and neglect-a clinician's handbook. Edinburgh: Churchill Livingstone, 1993:11937.

17 Rowan EL, Rowan JB, Langelier P. Women who molest children. Bull Am Acad Psychiatry Law 1990;18:79-83.

18 Matthews K. Working with female abusers. In: Elliott M, ed. Female sexual abuse of children-the ultimate taboo. London: Fomale sexual abuse

19 Memorandum of good practice on video-recorded interviews with child witnesses for criminal proceedings. views with child witn

20 Davies G, Wilson G, Mitchell R, Milson J. Video-taping children's evidence: an evaluation. London: Home Office, 1995. 